\title{
New Species of Rails (Aves: Rallidae) from an Archaeological Site on Huahine, Society Islands ${ }^{1}$
}

\author{
Feremy 7. Kirchman ${ }^{2,4}$ and David W. Steadman ${ }^{3}$
}

\begin{abstract}
We examined 50 bones previously assigned to "Gallirallus new sp." from the prehistoric (1,250-750 yr B.P.) Fa' ahia archaeological site on Huahine, Society Islands. Most of these specimens $(n=47)$, representing nearly all major cranial and postcranial skeletal elements, belong to a medium-sized flightless rail that we name Gallirallus storrsolsoni. Three femora represent a second species of extinct rail that we name Porphyrio mcnabi. With the description of these two species of rails, the total number of extinct species of land birds from the $\mathrm{Fa}^{6} \mathrm{a}$ hia site stands at seven, consisting of two rails, two doves, two parrots, and a starling. Fa'ahia also has yielded bones of six other species of land birds that no longer exist on Huahine but survive elsewhere in Oceania.
\end{abstract}

Fossil bONES FROM archaeological and paleontological sites on islands throughout Oceania have revealed extensive Holocene extinction of birds after colonization by humans and their commensals (James and Olson 1991, Olson and James 1991, Steadman 1995, in press, Worthy and Holdaway 2002). On a typical island in East Polynesia (Figure 1), 50 to $100 \%$ of the species of land birds that existed at human contact do not survive there today (Steadman in press). Especially prevalent among the East Polynesian extinct species are rails (Rallidae), most of which were flightless species endemic to single islands or to islands connected in the Pleistocene during periods of lowered sea levels. In this paper we describe two new species of

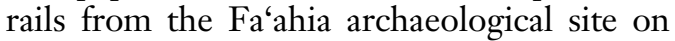
Huahine in the Society Islands.

\footnotetext{
${ }^{1}$ Financial support came from a McGlaughlin Fellowship to J.J.K. from the University of Florida College of Liberal Arts and Sciences, and NSF grants EAR9714819 and DEB-0228682 to D.W.S. Manuscript accepted 20 June 2005.

${ }^{2}$ Department of Zoology, University of Florida, Gainesville, Florida 32611.

${ }^{3}$ Florida Museum of Natural History, University of Florida, Gainesville, Florida 32611.

${ }^{4}$ Corresponding author: e-mail: jkirchman@zoo .ufl.edu; phone: 352-392-1721 x232; fax: 352-392-3704.
}

Pacific Science (2006), vol. 60, no. 2:281-297

(C) 2006 by University of Hawai'i Press

All rights reserved
The Fa'ahia site (Figure 2) was excavated by Yosihiko H. Sinoto and colleagues from 1973 to 1984 in cooperation with the Départment de Archéologie, Centre Polynésien des Sciences Humaines, Tahiti (DAPT). The cultural deposits at Fa'ahia were found submerged below the modern water table and contained exceptionally well-preserved organic materials, including wooden adze handles, tapa beaters, and parts of canoes (Sinoto 1975, 1979). Other objects preserved and recovered from $\mathrm{Fa}^{6}$ ahia include nonhuman bones representing food items of all sizes (fishes, reptiles, birds, and mammals) and a wide variety of artifacts and ornaments made of bone, shell, or stone. By East Polynesian standards, Fa'ahia is an early occupation site with radiocarbon dates ranging from ca. 1,250 to $750 \mathrm{yr}$ B.P. (= ca. A.D. 700 to 1200 [Sinoto 1983]). We note, however, that the chronology of human colonization in East Polynesia (the Cook Islands eastward, including the Society Islands) has been debated for decades (Sinoto 1970, Kirch 1984, 1986, 2000, Spriggs and Anderson 1993, Conte and Anderson 2003). Archaeological sites older than A.D. 1000 are scarce or absent in East Polynesia, although sedimentological and paleobotanical information suggests that people were present in the Society Islands and Cook Islands at least several centuries earlier than A.D. 1000 (Lepofsky et al. 1992, 1996, Kirch and Ellison 1994, Lepofsky 1995). In spite of uncertainty in the 


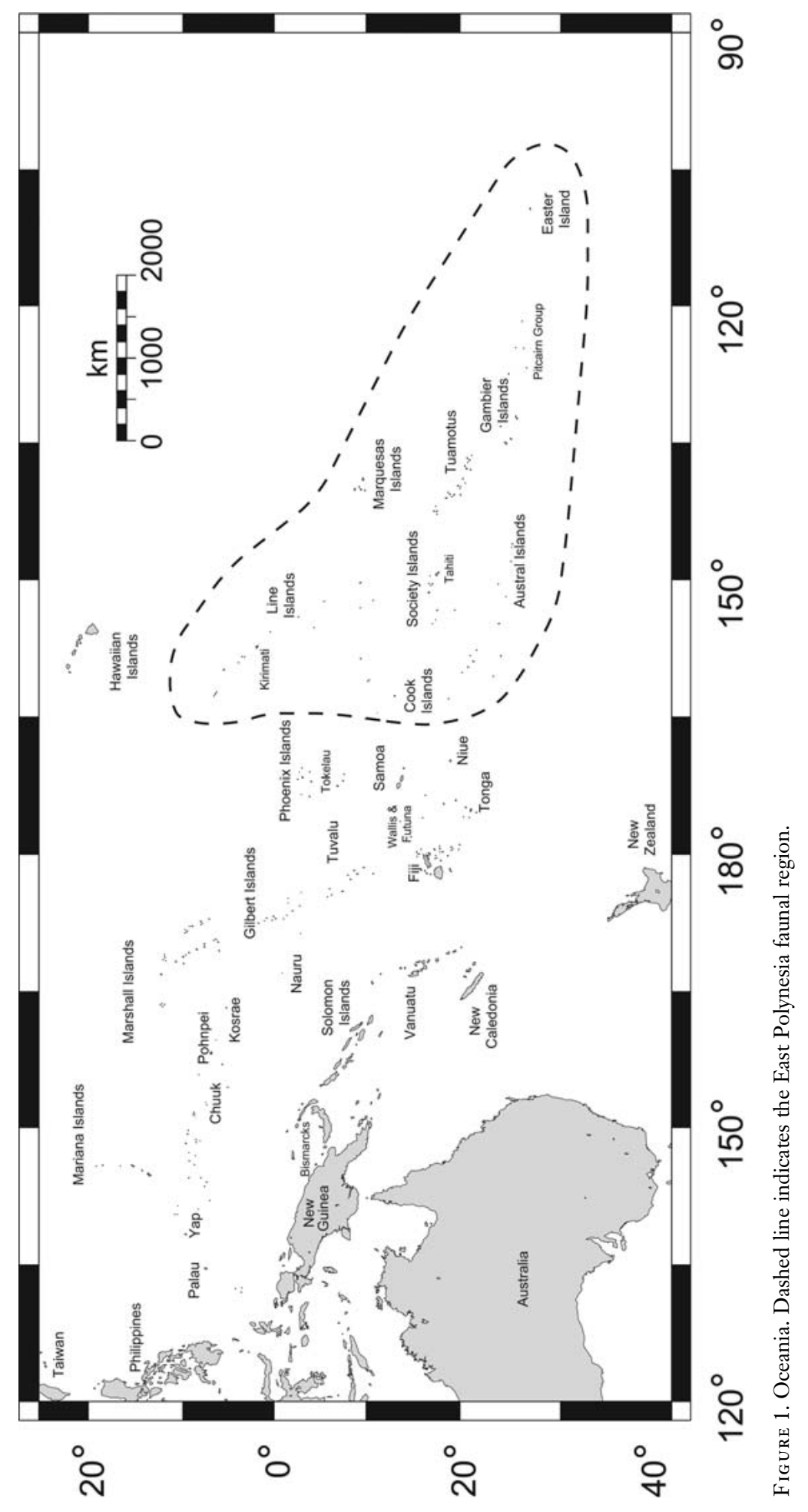




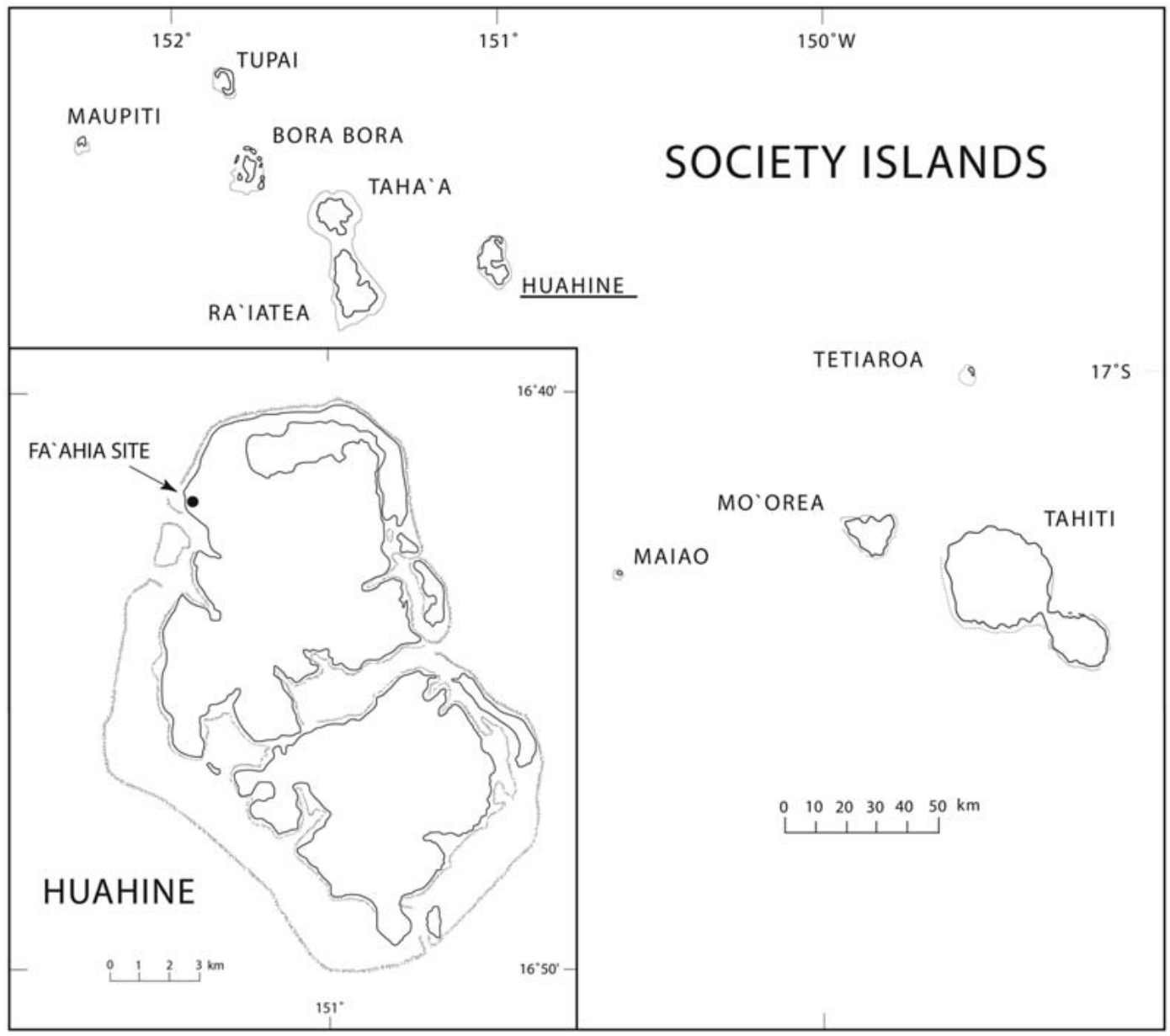

FIGURE 2. Society Islands, with inset of Huahine showing the location of the Fa'ahia archaeological site.

chronology of first arrival, there is a consistent pattern of heavy exploitation of native birds early in the archaeologically preserved cultural sequence in East Polynesia, which typically begins at ca. A.D. 1000 (Dye and Steadman 1990, Kirch et al. 1995, Steadman and Rolett 1996). In yielding bird bones that mainly represent extinct species, the zooarchaeological evidence from $\mathrm{Fa}^{\text {'ahia agrees with }}$ this pattern.

Over 300 bird bones were obtained at

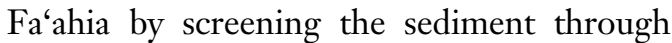
0.25 -in. (6.4-mm) mesh. Of 53 rail bones reported by Steadman and Pahlavan (1992), three were from Porzana tabuensis, a small species that is widespread in Polynesia but that no longer occurs on Huahine. The other 50 bones were assigned to a larger, presumably undescribed, flightless rail, referred to as "Gallirallus new sp." These 50 specimens are the basis of this paper.

\section{MATERIALS AND METHODS}

Skeletons used for comparisons are from the American Museum of Natural History (амNн), Bernice P. Bishop Museum (врвм), Delaware Museum of Natural History 
(DMNH), Florida Museum of Natural History, University of Florida (UF), University of Michigan Museum of Zoology (ummz), National Museum of Natural History, Smithsonian Institution (USNM), University of Washington Burke Museum (чwвм), and Yale Peabody Museum (YPM). We examined these modern specimens: Porzana (Poliolimnas) cinerea, DMNH 72836, 72906; Porzana tabuensis, uшвм 42501; Gallirallus striatus, AмNH 22981, USNM 85892, 559919, урм 107205; $G$. torquatus, AMNH 17715-17717, UMMZ 228275, 228280, USNM 290445; G. owstoni, UF 39918 , 39920,39921 , USNM 561968, 611816, 612616, 613738-613744, 614233-614235, 614771, 614772; G. australis greyi, uF 24326, 24327; G. a. australis, ҮРм 102249, 110760 , 110789, 110790, 110844; G. philippensis goodsoni, UF 39854, 39855; G. p. sethsmithi, UF 42902, 42933-42935; G. p. philippensis, UsNM 560651; G. p. yorki, USNM 560791; G. p. mellori, usNм 620196; G. p. ecaudatus, uшвм 42863, 42865, 42866; G. ["Nesoclopeus"] woodfordi, uf 39399, 39406, 39409, 39547, 39556, 39574; Gallinula chloropus, uf 39927; Porphyrio porphyrio samoensis, UF 39332, 39388, 39407, USNM 561547, 561549, 5461551; $P$. p. poliocephalus, USNM $34212 ;$ P. p. pulverulentus, UsNM 226035, 292296, 292297; Porphyrio martinicus, uf 42417, 42419; Porphyrio alleni, uf 34172, 38839. We also examined these fossil specimens: Gallirallus ripleyi humerus, uf 51402, ulnae, UF 54901, 55215, carpometacarpi, UF 54700,54988 , femur, uf 51320 , tibiotarsi, uf 54732, 54985, USNM 402895 (holotype), tarsometatarsi, UF 54761, 55223, USNM 402895 (holotype); G. vekamatolu humerus, UF 52333, ulna, uf 51734, femora, uf 52020, 52058, tibiotarsi, uf 51729, 52211, tarsometatarsus, uf 51991 (holotype); Porphyrio paepae femora, врвм 165649, 166424, 166426, 166434 , tibiotarsus, врвм 165651, synsacrum, врвм 165656. We follow Taylor (1998) for subspecies-level taxonomy.

Measurements were taken with dial calipers (Helios), rounded to the nearest 0.1 $\mathrm{mm}$. To assess the degree of flightlessness in each species, we performed a principal components analysis (PCA) using the software package SPSS 13.0. Unweighted character means (natural [base $e$ ] log-transformed) for each species were used for the PCA. Characters used in the PCA were chosen on the basis of availability in fossil specimens from Huahine. Osteological terminology follows Baumel and Witmer (1993).

\section{COMPARATIVE OSTEOLOGY AND SYSTEMATICS \\ Family Rallidae \\ Genus Gallirallus Lafresnaye, 1841}

We regard all "typical long-billed rails" from Oceania as species of Gallirallus sensu lato, distinguishing them from the similarly sized swamphens (Porphyrio), moorhens (Gallinula), and coots (Fulica), and the much smaller crakes (Porzana and Poliolimnas). This treatment departs slightly from the classification of Olson (1973a), who provisionally retained woodfordi of the Solomon Islands and poecilopterus of Fiji in the genus Nesoclopeus but highlighted their close affinity with Gallirallus. Livezey $(1998,2003)$ retained the genera Nesoclopeus, Tricholimnas, Cabalus, and Habropteryx for some species of long-billed rails but acknowledged the difficulty of establishing generic-level relationships in this group on the basis of osteology. We refer 47 of the fossils from Huahine to Gallirallus rather than to other genera of Oceanic rails because of the following characters. Skull: frontals narrow, concave. Rostrum: long, narrow, and shallow with elongate nares. Humerus: fossa pneumotricipitalis deep and wide with prominent crus ventrale fossae. Ulna: thin in cranial aspect with rectangular (rather than rounded) margo cranialis. Pelvis: ala preacetabularis ilii broadly continuous with crista dorsalis of synsacrum. Femur: distal end of corpus femoris becomes gradually wider; condylus medialis subcircular in medial aspect; impresso ansae musculo iliofibularis abuts suclus fibularis. Tibiotarsus: impresso ligamentum collateralis medialis deep and wide; facies articularis femoris large; condylus medialis subcircular in medial aspect. Tarsometatarsus: corpus tarsometatarsi much wider than deep; medial sulcus hypotarsi not enclosed; fossa metatarsi I short and shallow. 


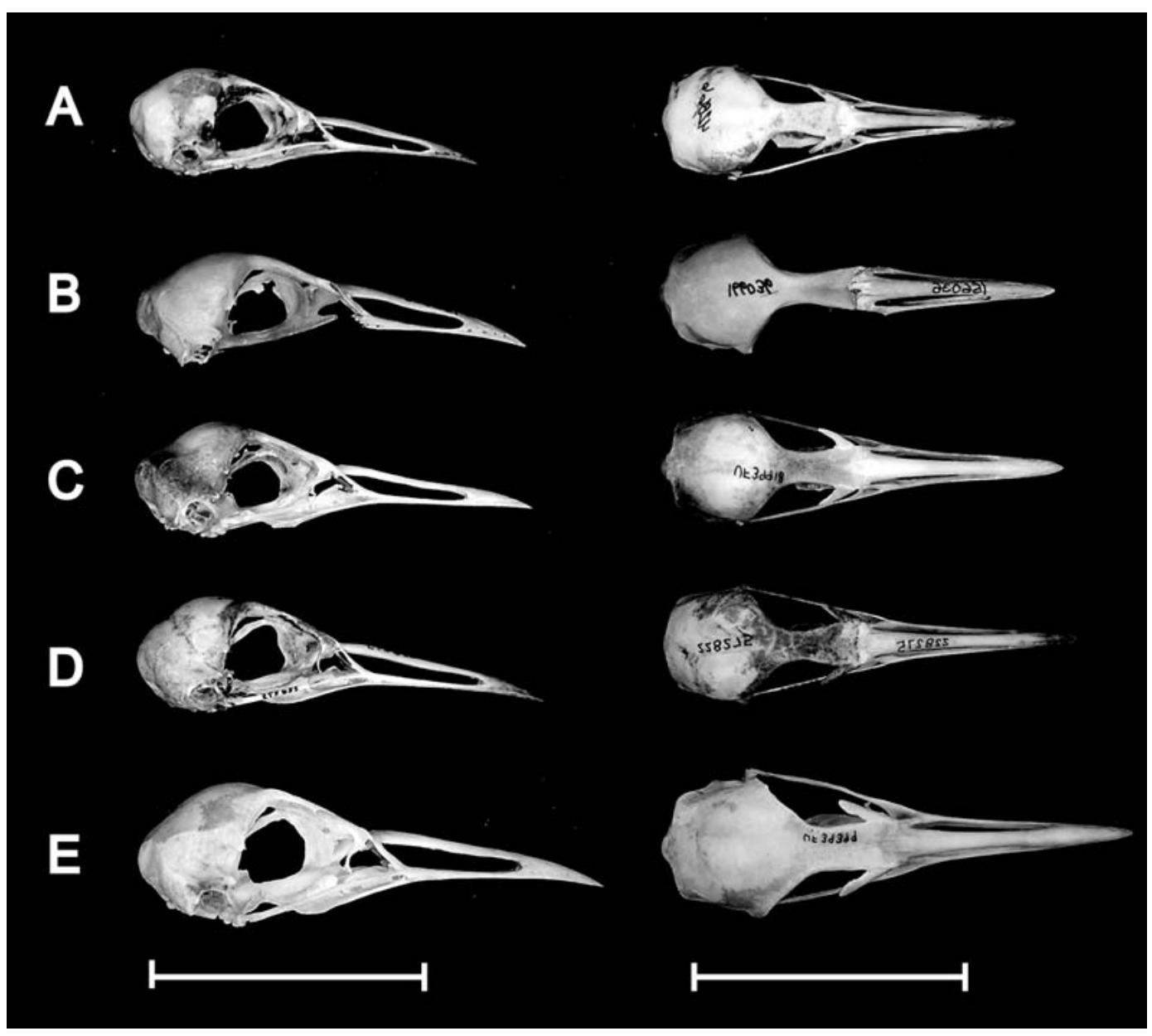

Figure 3. Lateral (left) and dorsal (right) views of the skulls of Gallirallus. A, G. philippensis, uwbm 42866. B, G. storrsolsoni, holotype, врвм 166036. C, G. owstoni, uf 39918. D, G. torquatus, uмmz 228275. E, G. woodfordi, uf 39399. Scale bars $=50 \mathrm{~mm}$

Gallirallus storrsolsoni Kirchman \& Steadman, n. sp.

Figures $3 B ; 4 B ; 5 B, E, H, K$

holotype. Complete cranium and rostrum, врвм 166036 (Figure 3).

PaRATYPEs. Crania, ВРвм 166021, 166026, 168015, DAPT 139; rostrum, DAPT 21 ; vertebrae, врвм 166024, 166025, 166035, 168001, 168002, 168078, DAPT 13, 14, 25, 60, $61,122,143,144,145,163$; rib, врвм 166018; sterna, врвм 166017, 166027; humerus, врвм 166022 (left [1]); ulnae, врвм 166033 (1),
168121 (l), 168150 (right [r]); radius, врвм 168056 (r); carpometacarpus, врвм 168165 (l); synsacrum, вРвм 166020; femora, вРвм 168131 (r), DAPT 27/105 (r); tibiotarsi, ВРВм 166023 (l), 166032 (r), 168028 (l), 168046 (r), 168123 (r), 168149 (l), 168170 (l), DAPT 47 (r), 55 (l), 119 (l); tarsometatarsi, врвм 166034 (r), 168124 (r), DAPT 7 (r).

DiAgNosis. A medium-sized species of Gallirallus (Table 1) distinguished from congeners in Oceania as follows. Skull (Figure 3): fossa temporalis deeply excavated, clearly emarginated by crista temporalis and extends 


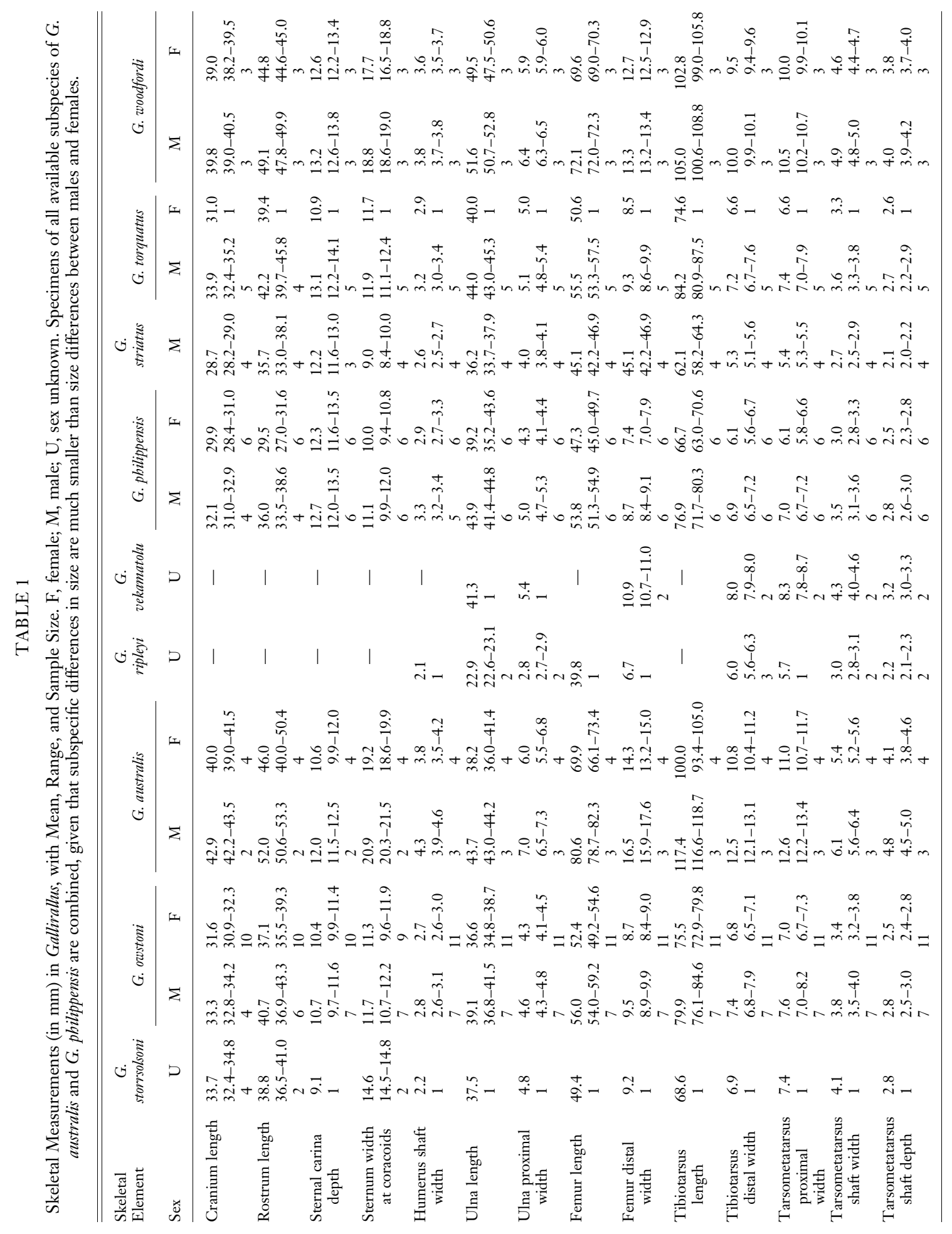




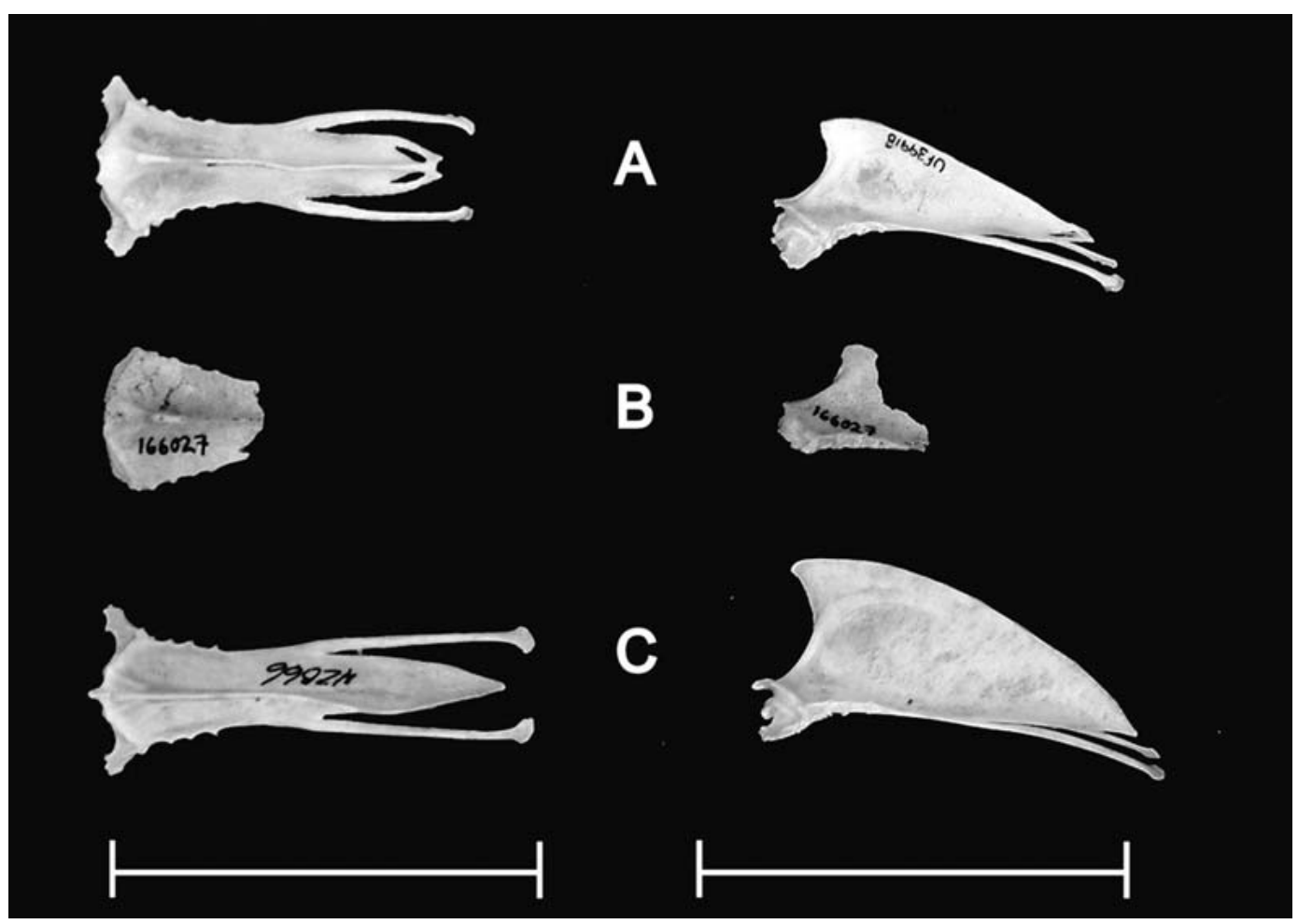

Figure 4. Ventral (left) and lateral (right) views of the sterna of Gallirallus. A, G. owstoni, uf 39918. B, G. storrsolsoni, врвм 166027. $C$, G. philippensis, uшвм 42866. Scale bars $=50 \mathrm{~mm}$.

more caudally; cranium with prominent crista nuchalis transversae and a low, broad calveria (as in G. woodfordi); in dorsal aspect, the posterior margins of the orbits abruptly angle away from the midline; the lamina parasphenoidalis is well emarginated caudally. Sternum (Figure 4): spina externa of rostrum sterni absent. Humerus (Figure 5): incisura capitus narrows proximally in caudal aspect; crista deltopectoralis rectangular, parallel to corpus humeri; corpus humeri thin, round in cross-section. Ulna (Figure 5): corpus ulnaris straight and dorsoventrally flattened, more so than even in flightless $G$. owstoni, G. vekamatolu, or G. australis; impressio brachialis deep and clearly emarginated. Synsacrum: broad in ventral aspect, gradually narrowing caudally. Femur (Figure 8): corpus femoris robust, approaching but not surpassing the stoutness of G. vekamatolu. Tibiotarsus (Figure 5): proportionally short (as in G. australis); incisura intercondylaris wide, resulting from an obtuse angle between the condylus medialis and condylus lateralis; juncture of condylus medialis with facies caudalis of corpus tibiotarsis abrupt rather than gradually sloping. Tarsometatarsus (Figure 5): corpus tarsometatarsi dorsoventrally flattened with a width-to-depth ratio (1.46) greater than in other species (1.21-1.36); viewed medially, the proximal one-third of corpus tarsometatarsi slopes toward the hypotarsus rather than being perpendicular to facies dorsalis.

etymology. Named after Storrs L. Olson in recognition of his unparalleled contributions to the evolution, systematics, and paleontology of flightless rails on islands.

remarks. Gallirallus storrsolsoni is a medium-sized species that, in overall size, resembles G. owstoni, G. philippensis, G. striatus, and G. torquatus. It is larger than G. ripleyi and smaller than $G$. australis, G. vekamatolu, 


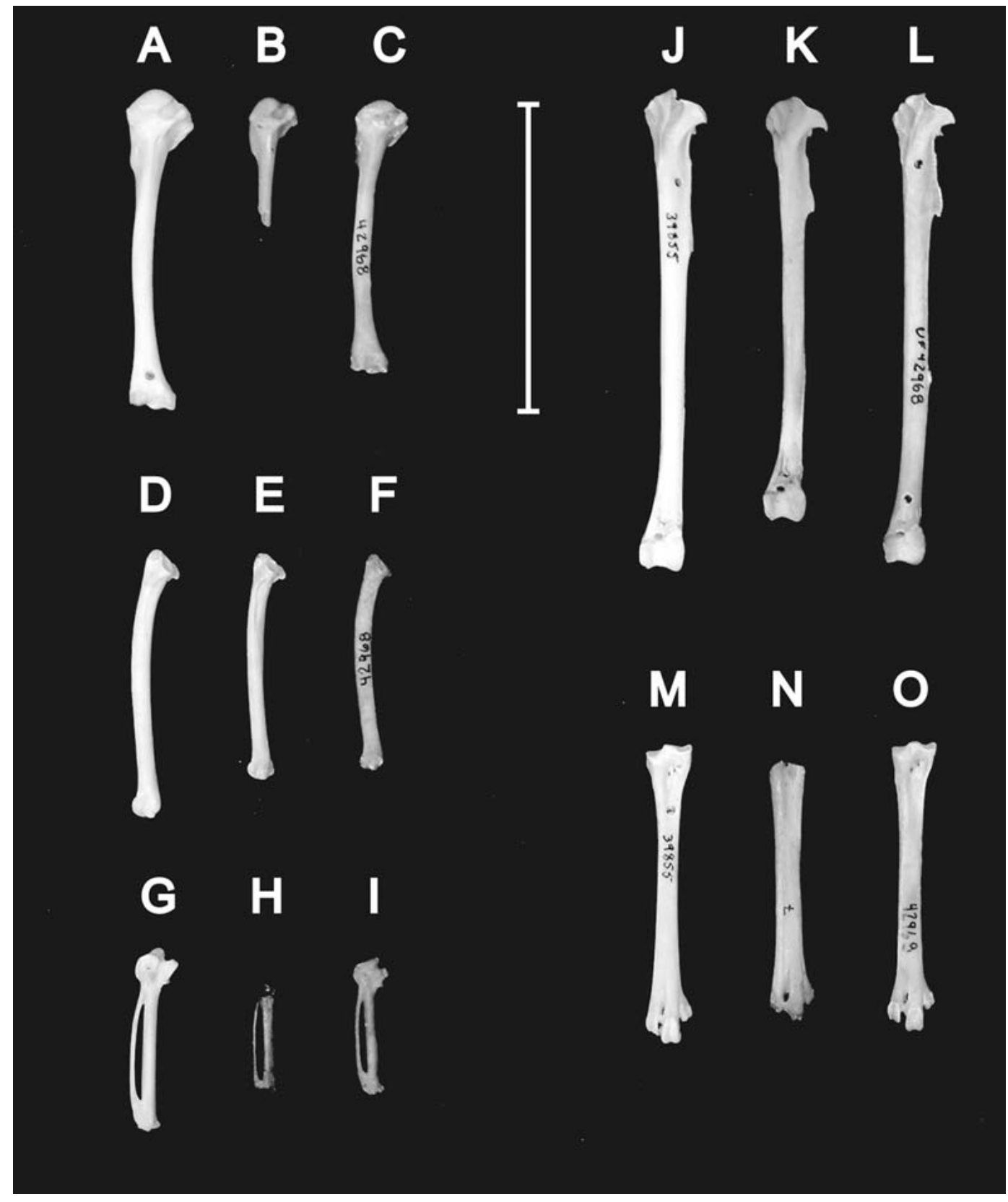

FIgURE 5. Humeri $(A-C)$, ulnae $(D-F)$, carpometacarpi $(G-I)$, tibiotarsi $(\mathcal{f}-L)$, and tarsometatarsi $(M-O)$ of Gallirallus philippensis $(A, D, G, \mathcal{F}, M$, all from Uғ 39855$)$, G. storrsolsoni (B, врвм 166022; $E$, врвм $166033 ; H$, врвм $168165 ; K$, врвм 166023; $N$, DAPт 7), and $G$. owstoni $(C, F, I, L, O$, all from uf 42968). Scale bar $=50 \mathrm{~mm}$. 
TABLE 2

Principal Components Analysis Correlation Coefficients of 16 Skeletal Measurements from Eight Species of Gallirallus (See Text, Figure 6)

\begin{tabular}{lcrrr}
\hline \hline & \multicolumn{3}{c}{ Correlation Coefficients } \\
\cline { 2 - 5 } Skeletal Element & PC1 & PC2 & PC3 & PC4 \\
\hline Sternum, width at coracoids & .265 & -.093 & -.045 & .019 \\
Sternum, keel depth & .097 & .177 & .037 & .027 \\
Humerus, shaft width & .219 & .089 & .077 & -.014 \\
Ulna, total length & .146 & .110 & -.035 & .003 \\
Ulna, proximal width & .217 & .024 & -.013 & .023 \\
Ulna, shaft width & .203 & .049 & .025 & .030 \\
Carpometacarpus, intermetacarpal space length & .163 & .165 & -.098 & -.022 \\
Femur, total length & .224 & .021 & .021 & -.002 \\
Femur, distal width & .293 & -.047 & .004 & -.002 \\
Femur, shaft width & .255 & -.024 & -.002 & .015 \\
Tibiotarsus, total length & .222 & .014 & .023 & -.031 \\
Tibiotarsus, distal width & .263 & -.048 & .018 & -.011 \\
Tibiotarsus, shaft width & .263 & -.012 & .002 & -.030 \\
Tarsometatarsus, proximal width & .258 & -.061 & .004 & -.013 \\
Tarsometatarsus, shaft width & .253 & -.067 & -.029 & .018 \\
Tarsometatarsus, shaft depth & .262 & -.037 & .004 & .004 \\
Percentage total variance explained & 85.81 & 10.65 & 2.33 & 0.61 \\
\hline
\end{tabular}

and G. woodfordi. Gallirallus storrsolsoni has a greatly reduced carina sterni, small wing elements, and stout leg elements as in its flightless congeners. The diagnosis of flightlessness is supported by morphometric comparisons with species of Gallirallus that are known to be either volant or flightless. Correlation coefficients of the first four principal components (PC), which together account for $99.4 \%$ of morphological variance, indicate that PC 1 describes variation in overall size and the degree of reduction of the carina sterni, ulna, and carpometacarpus, and that PC 2 is a description of keel and wing reduction, and leg-bone robustness (Table 2). A plot of PC 1 versus PC 2, summarizing $96.5 \%$ of morphometric variance, clusters $G$. storrsolsoni with flightless rather than volant congeners (Figure 6).

The material from $\mathrm{Fa}^{6}$ ahia represents six individuals, minimally. Because of the excellent preservational environment at the $\mathrm{Fa}^{\text {' }} \mathrm{a}$ hia site, even the most delicate elements of the skeleton of G. storrsolsoni are known, including one partial sternum (UF 166027) that still retains the anterior margin of the carina. Outside the New Zealand region, such pres- ervation is unique; all other Gallirallus species described from fossils, G. ripleyi (Mangaia, Cook Islands), G. buiatua (Niue), and $G$. vekamatolu ('Eua, Tonga), were considered to be flightless on the basis of limb-bone proportions (Steadman 1987, Steadman et al. 2000, Kirchman and Steadman 2005).

\section{Genus Porphyrio Brisson, 1760}

We refer three femora from the Fa'ahia archaeological site (вРвм 166031, DАРт 39, 53) to Porphyrio rather than the other genera of large Pacific rails (Gallirallus, Gallinula, Fulica) because of these characters: in proximal aspect, more obtuse angle formed at the junction of the impressiones obturatoriae and trochanter femoris; impressiones obturatoriae more prominent, leading to a more concave proximoposterior area of corpus femoris; similar size and position of the impressiones iliotrochanteria and linea intermuscularis caudalis; corpus femoris overall more slender; distal end of corpus femoris not expanded laterally until the epicondylus lateralis is reached; rotular groove more narrow; in posterior aspect, medial margin of 


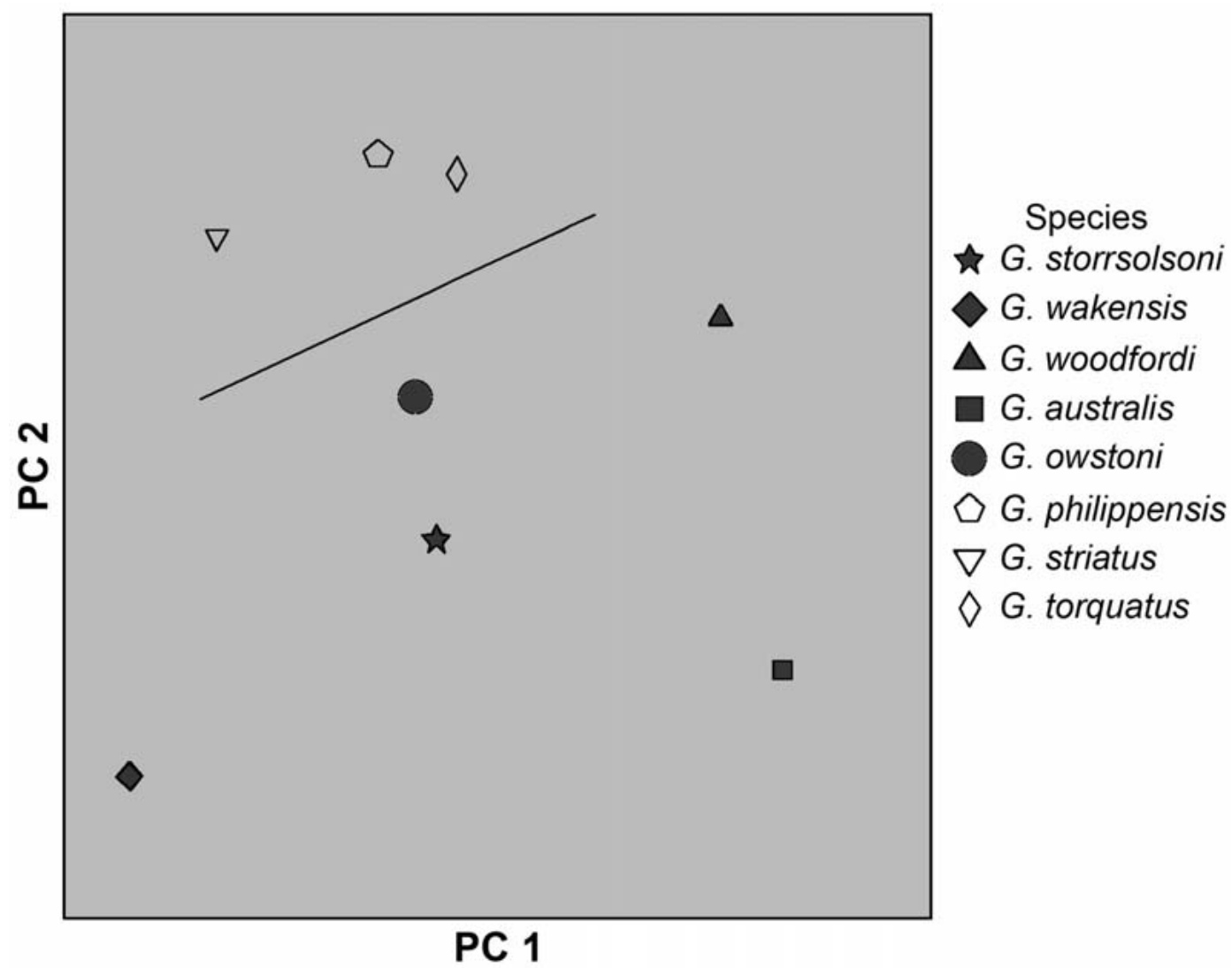

Figure 6. Plot of mean scores for eight species of Gallirallus on the first two principal components (summarizing $96.5 \%$ of variance) of 16 postcranial skeletal measurements. Hollow symbols are volant species; filled symbols are flightless species. The line indicates a hypothesized threshold for flightlessness.

the condylus medialis oriented roughly parallel to the shaft rather than diagonal.

Porphyrio mcnabi Kirchman \& Steadman, n. sp.

Figures $7 A, 8 D$

hоLотуре. Nearly complete right femur, врвм 166031 (Figures 7, 8).

paratypes. Distal left femur, Dapt 53. Left femur lacking distal end, DAPT 39.

diagnosis. A small species of Porphyrio (Table 3) distinguished from congeners as follows: impressiones iliotrochanteris extends farther (more distad) along corpus femoris than in $P$. paepae; in lateral aspect, corpus femoris straighter than in all but $P$. paepae; in lateral aspect, crista trochanteris more rounded (less flared) on dorsal surface than in $P$. paepae; most proximal section of linea intermuscularis caudalis (= dorsalis) weakly developed (thicker and more protrudent in P. paepae).

ETYMOlogy. Named after Brian K. $\mathrm{McNab}$ in recognition of his important research on the evolution and physiological ecology of flightless birds, especially rails, on oceanic islands.

Figure 7. Cranial (upper) and caudal (lower) views of femora of Porphyrio. A, P. mcnabi, holotype, врвм 166031. B, P. paepae, врвм 165649. C, P. martinicus, uf 42419. D, P. porphyrio, uf 39407. Scale bars $=50 \mathrm{~mm}$. 


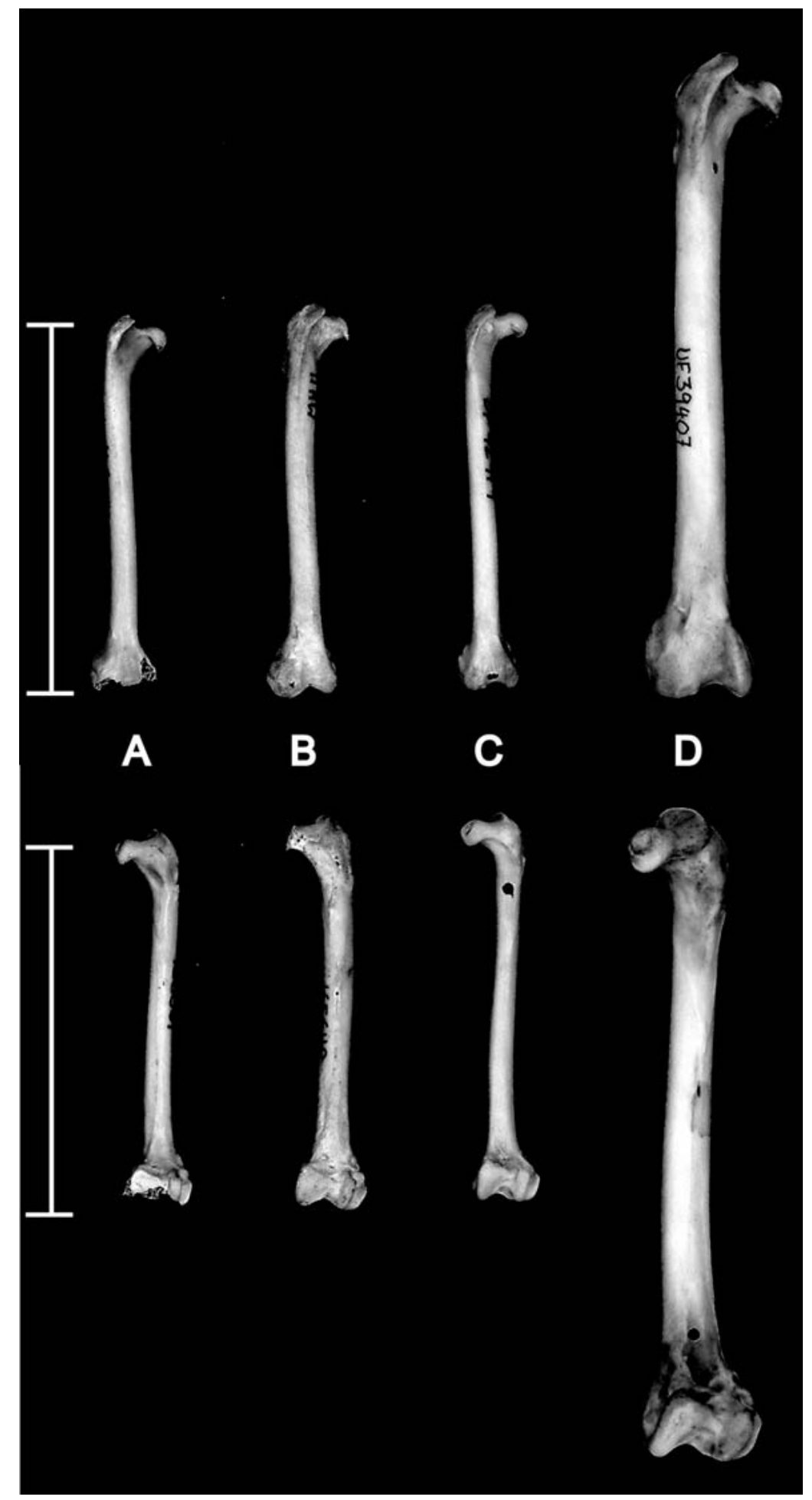



remarks. Porphyrio mcnabi is a small species that, in overall body size, resembles $P$. paepae and $P$. martinicus. It is larger than $P$. flavirostris and $P$. alleni and is exceeded in size by $P$. porphyrio, P. mantelli, P. hochstetteri, $P$. kukwiedii, and Porphyrio undescribed species A and B (see later in this section). The three femora of $P$. mcnabi were among the 50 bones listed as "Gallirallus new sp." in Steadman and Pahlavan (1992). It is likely that врвм 166031 represents an adult female (smaller), whereas DAPT 39 (left) and DAPT 53 (right) represent a single juvenile male (larger). That DAPT 39 and 52 are from a juvenile is supported by their porous surfaces, thin-walled shafts, and being slightly more gracile than would be expected in an adult.

Lacking elements of the wing or pectoral girdle, we cannot say whether Porphyrio mcnabi was flightless. The extant P. martinicus, P. flavirostris, $P$. alleni (all small), and $P$. porphyrio (large) are all volant. The four very large, extinct species (P. kukwiedii of New Caledonia, P. mantelli of New Zealand, Porphyrio undescribed species A of New Ireland, Bismarck Archipelago, and Porphyrio undescribed species B of Buka, Solomon Islands) all were flightless, as is the very large, extant $P$. hochstetteri of New Zealand (Balouet and Olson 1989, Worthy and Holdaway 2002, Steadman in press). The small, extinct $P$. paepae of the Marquesas had somewhat reduced wings but perhaps was still volant (Steadman 1988).

\section{DISCUSSION}

\section{Flightlessness}

Rails are developmentally predisposed to become flightless (Olson 1973b, Feduccia 2000), and scores of neotenic flightless species have evolved independently on oceanic islands that lack indigenous placental carnivores. The hypothesis that flightlessness evolves as a means of energy conservation is supported by the basal metabolic rates in flightless species of insular rails being lower than those of their volant relatives $(\mathrm{McNab}$ 1994a,b). This finding, coupled with the observation that metabolic rate also correlates positively with relative pectoral muscle mass
(McNab 1994a, 2002), suggests that selection for reduced pectoral and wing musculature is the likely cause of insular avian flightlessness.

Skeletons of flightless rails are distinguished from those of volant relatives by having reduced sternal keels (carina sterni) and shorter, thinner wing bones. Livezey (1998, 2003) has shown that the degree of reduction of pectoral elements varies greatly even among flightless species. Indeed there appears to be a continuum of wing reduction among flightless rails that mirrors the graded reduction in energy expenditure ( $\mathrm{McNab}$ 2002). Our morphometric analysis of Gallirallus skeletons indicates that some species, such as G. australis, have greatly reduced carina sterni and wing elements, whereas other extant species known to be flightless, such as G. owstoni, seem to be near the threshold of flight.

\section{Biogeography}

Of the \pm 18 living and extinct species of Gallirallus sensu lato that have been named, all but two are flightless species endemic to Oceania on single islands or on multiple islands that were connected during the late Pleistocene period of lowered sea levels (Steadman 1987, in press, Diamond 1991, Mayr and Diamond 2001). The two extant, volant species, G. torquatus and G. philippensis, are sympatric in the Philippines, Sulawesi, and New Guinea, although the latter species is very widespread, its distribution extending south to Australia and New Zealand and east in Oceania to Samoa. Flightless species of Gallirallus have evolved on nearly all major archipelagos in Oceania from the Ryukyu Islands of southern Japan, south to New Zealand's Chatham Islands, and east to the Society Islands. Bones (still undescribed) of Gallirallus also have been found in archaeological sites on four islands in the Marquesas (Steadman 1989a, Steadman and Rolett 1996). Gallirallus apparently never made it as far northeast in Oceania as the Hawaiian Islands or as far southeast in Polynesia as Henderson Island, both of which have good Holocene fossil bird records (James and Olson 1991, Olson and James 1991, Wragg 1995, Steadman in press). 
Gallirallus storrsolsoni is not the only species of flightless rail known from the Society Islands. The extinct G. pacificus was discovered on Tahiti by naturalists from Captain James Cook's second voyage (1777), but no specimens exist, and the species is known only from a painting by Georg Forster. The plumage, soft-part colors, and bill shape make it clear that pacificus is correctly accomodated in Gallirallus. Measurements made by Storrs L. Olson in 1998 (pers. comm.) from Forster's original, full-scale painting in the British Museum of Natural History indicate that $G$. pacificus was a much smaller rail than $G$. storrsolsoni. For example, the culmen (with epidermal sheath) in G. pacificus is $28.8 \mathrm{~mm}$, whereas the rostrum (without epidermal sheath) in G. storrsolsoni is $36.5-41.0 \mathrm{~mm}$ (Table 1). The tarsus (incuding scutes) in $G$. pacificus is $33.8 \mathrm{~mm}$, whereas the tarsometatarsus (without epidermal sheath) in G. storrsolsoni is ca. $48.5 \mathrm{~mm}$, based on a composite of two incomplete specimens (DAPT 7, вPBM 166034). Gallirallus pacificus is presumed to be flightless on the basis of the short wings in the painting; although this is likely, in the absence of specimens it cannot be verified in the painting. The possible former existence of G. pacificus on Mehetia (Taylor 1998), a small island $110 \mathrm{~km}$ east-southeast of Tahiti, is unsubstantiated and doubtful.

Based on its geological and geographical setting, any flightless species on Huahine is likely to have been endemic to the island. The geological age of Huahine is ca. 3 million yr (Dickinson 1998). It is an eroded volcanic island surrounded by a broad fringing reef, outside of which the water becomes very deep. The nearest island is Ra'iatea, ca. $35 \mathrm{~km}$ to the west. Huahine never was connected to any other island, even during the lowered sea levels of Pleistocene glacial intervals, when Ra'iatea still would have been ca. $30 \mathrm{~km}$ away.

The genus Porphyrio is widespread in tropical and subtropical lowlands. Two extant, volant species, P. martinicus and P. flavirostris, are confined to the Americas. All other species are from the Old World, with extant, volant P. alleni in Africa and the larger, extant, volant $P$. porphyrio very widespread from southern Europe and Africa eastward across southern Asia, Indonesia, and Australia to Oceania as far east as Fiji, Tonga, Samoa, and Niue (Taylor 1998:464, 465). No species of Porphyrio inhabit East Polynesia today. The radiation of certainly or presumably flightless species of Porphyrio is confined to Oceania (Balouet and Olson 1989, Worthy and Holdaway 2002, Steadman in press). The only flightless species that still exists is P. hochstetteri from South Island, New Zealand. Known extinct forms of Porphyrio are P. mantelli (North Island, New Zealand), $P$. albus (Lord Howe Island), P. kukwiedii (New Caledonia), and Porphyrio undescribed sp. A (New Ireland) and sp. B (Buka, Solomon Islands). Each of these species was as large as or larger than the massive $P$. hochstetteri, which is the largest extant form.

Finally, Porphyrio paepae was a smaller, probably flightless swamphen that is known from Hiva $\mathrm{Oa}$ and Tahuata, two islands only $3 \mathrm{~km}$ from each other in the Marquesas (Steadman 1988). At the time of its description, $P$. paepae was the only species of Porphyrio known from East Polynesia. The discovery of P. mcnabi in the Society Islands helps to bridge the formerly huge distributional gap of the genus (from Niue to the Marquesas) and strengthens the likelihood that a substantial radiation of swamphens once existed in East Polynesia. At this point, we cannot say whether this radiation was of Old World or New World origin. Osteological synapomorphies that ally $P$. paepae and $P$. monabi with either the New World species $(P$. martinicus, P. flavirostris) or the Old World $P$. porphyrio s.l. have not been discerned. Given the propensity in $P$. martinicus and $P$. flavirostris for unpredictable, long-distance dispersal (Remsen and Parker 1990), the geographic origin of East Polynesian Porphyrio species remains an open question.

\section{Avian Extinction on Huabine}

The Fa'ahia archaeological site contained the bones of 15 resident species of seabirds, three migratory species of shorebirds, and 16 species of resident land birds (Steadman and Pahlavan 1992, Steadman in press). Of the 
15 seabirds, 12 no longer occur on Huahine, including the extinct gull Larus utunui (Steadman 2002). The other 11 species of seabirds still are found, at least locally, elsewhere in Oceania. Each of the migratory shorebirds, on the other hand, may visit Huahine seasonally today. Of the 16 species of land birds from $\mathrm{Fa}^{6}$ ahia, 13 no longer occur on Huahine. They consist of the locally extripated heron Butorides (Ardeola) striatus, rail Porzana tabuensis, dove Gallicolumba erythroptera, pigeons Ducula galeata and D. aurorae, and warbler Acrocephalus caffer. Aside from Gallirallus storrsolsoni and Porphyrio mcnabi, the extinct species of land birds from $\mathrm{Fa}^{\text {ahahia include }}$ the doves Gallicolumba nui and Macropygia arevarevauupa, lorikeets Vini vidivici and V. sinotoi, and starling Aplonis diluvialis (Steadman and Zarriello 1987, Steadman 1989b, 1992).

The survivors are the very widespread heron Egretta sacra and two species endemic to the Society Islands, the dove Ptilinopus purpuratus and kingfisher Halcyon tuta. Also extant on Huahine is the very widespread duck Anas superciliosa, which was not found among the bird bones from Fa'ahia. Two additional species of land birds, the lorikeet Vini peruviana and swiftlet Collocalia leucophaea, are unknown at the $\mathrm{Fa}^{\text {'ahia }}$ site but were recorded from Huahine in the nineteenth century, although they no longer persist on the island (Steadman in press). Altogether, 19 species of land birds have been recorded from Huahine, which is the same number that is known from much-larger Tahiti, which has no fossil record of birds. If the prehistoric bird community of Huahine were entirely revealed, we believe that it also would include a species of Prosobonia sandpiper, Cyanoramphus parrot, and Pomarea monarch, three genera recorded on at least two other islands in the Society Group.

\section{ACKNOWLEDGMENTS}

For access to modern specimens, we thank the curatorial staffs of the eight museums listed in Materials and Methods. Carla Kishinami and Yosihiko Sinoto kindly provided access to the prehistoric bones from Huahine. We are grateful to Storrs Olson for sharing his measurements of Forster's painting of Gallirallus pacificus. We thank Storrs Olson and an anonymous reviewer for insightful comments that improved the manuscript.

\section{Literature Cited}

Balouet, J. C., and S. L. Olson. 1989. Fossil birds from late Quaternary deposits in New Caledonia. Smithson. Contrib. Zool. 469.

Baumel, J. L., and L. M. Witmer. 1993. Osteologia. Pages 45-132 in J. J. Baumel, A. S. King, J. E. Breazile, H. E. Evans, and J. C. Vanden Berge, eds. Handbook of avian anatomy: Nomina anatomica avium, 2nd ed. Nuttall Ornithological Club, Cambridge, Massachusetts.

Conte, E., and A. Anderson. 2003. Radiocarbon ages for two sites on Ua Huka, Marquesas. Asian Perspect. 42:155-160.

Diamond, J. M. 1991. A new species of rail from the Solomon Islands and convergent evolution of insular flightlessness. Auk 108:461-470.

Dickinson, W. R. 1998. Geomorphology and geodynamics of the Cook-Austral Island Seamount Chain in the South Pacific Ocean: Implications for hotspots and plumes. Int. Geol. Rev. 40:1039-1075.

Dye, T., and D. W. Steadman. 1990. Polynesian ancestors and their animal world. Am. Sci. 78:209-217.

Feduccia, A. 2000. The origin and evolution of birds, 2nd ed. Yale University Press, New Haven, Connecticut.

James, H. F., and S. L. Olson. 1991. Description of thirty-two new species of birds from the Hawaiian Islands: Part II. Passeriformes. Ornithol. Monogr. 46.

Kirch, P. V. 1984. The evolution of the Polynesian chiefdoms. Cambridge University Press, Cambridge, United Kingdom.

- 1986. Rethinking East Polynesian prehistory. J. Polynesian Soc. 95:9-40. 2000. On the road of the winds: An archaeological history of the Pacific islands before European contact. University of California Press, Berkeley.

Kirch, P. V., and J. Ellison. 1994. Palaeoenvironmental evidence for human coloniza- 
tion of remote Oceanic islands. Antiquity 68:310-321.

Kirch, P. V., D. W. Steadman, V. L. Butler, J. Hather, and M. Weisler. 1995. Prehistory and human ecology in eastern Polynesia: Excavations at Tangatatau Rockshelter, Mangaia, Cook Islands. Archaeol. Oceania 30:47-65.

Kirchman, J. J., and D. W. Steadman. 2005. Rails (Aves: Rallidae: Gallirallus) from prehistoric sites in the Kingdom of Tonga, including description of a new species. Proc. Biol. Soc. Wash. 118:465-477.

Lepofsky, D. 1995. A radiocarbon chronology for prehistoric agriculture in the Society Islands, French Polynesia. Radiocarbon 37:917-930.

Lepofsky, D., H. C. Harries, and M. Kellum. 1992. Early coconuts on Mo'orea Island, French Polynesia. J. Polynesian Soc. 101: 299-308.

Lepofsky, D., P. V. Kirch, and K. P. Lertzman. 1996. Stratigraphic and paleobotanical evidence for prehistoric humaninduced environmental disturbance on Mo'orea, French Polynesia. Pac. Sci. 50: 253-273.

Livezey, B. C. 1998. A phylogenetic analysis of the Gruiformes (Aves) based on morphological characters, with an emphasis on the rails (Rallidae). Philos. Trans. R. Soc. Lond. B Biol. Sci. 353:2077-2151.

. 2003. Evolution of flightlessness in rails (Gruiformes: Rallidae): Phylogenetic, ecomorphological, and ontogenetic perspectives. Ornithol. Monogr. 53.

Mayr, E., and J. Diamond. 2001. The birds of northern Melanesia. Oxford University Press, Oxford, United Kingdom.

McNab, B. K. 1994a. Energy conservation and the evolution of flightlessness in birds. Am. Nat. 144:628-642.

1994b. Resource use and the survival of land and freshwater vertebrates on oceanic islands. Am. Nat. 144:643-660.

. 2002. The physiological ecology of vertebrates: A view from energetics. Cornell University Press, Ithaca, New York.

Olson, S. L. 1973a. A classification of the Rallidae. Wilson Bull. 85:381-416. 1973b. Evolution of the rails of the South Atlantic islands (Aves: Rallidae). Smithson. Contrib. Zool. 152.

Olson, S. L., and H. F. James. 1991. Description of thirty-two new species of birds from the Hawaiian Islands: Part I. NonPasseriformes. Ornithol. Monogr. 46.

Remsen, J. V., Jr., and T. A. Parker III. 1990. Seasonal distribution of the azure gallinule (Porphyrula flavirostris), with comments on vagrancy in rails and gallinules. Wilson Bull. 102:380-399.

Sinoto, Y. H. 1970. An archaeologically based assessment of the Marquesas Islands as a dispersal center in East Polynesia. Pac. Anthropol. Rec. 11:105-132.

- 1975. Report on the preliminary excavation of an early habitation site on Huahine, Society Islands. J. Soc. Océan. 31:143-186.

-. 1979. Excavations on Huahine, French Polynesia. Pac. Stud. 3:1-40. 1983. Archaeological excavations of the Vaito'tia and Fa'ahia sites on Huahine Island, French Polynesia. Natl. Geogr. Res. 15:583-599.

Spriggs, M., and A. Anderson. 1993. Late colonization of East Polynesia. Antiquity 67:200-217.

Steadman, D. W. 1987. Two new species of rails (Aves: Rallidae) from Mangaia, southern Cook Islands. Pac. Sci. 40:38-54.

- 1988. A new species of Porphyrio (Aves: Rallidae) from archaeological sites in the Marquesas Islands. Proc. Biol. Soc. Wash. 101:162-170.

- 1989a. Extinction of birds in eastern Polynesia: A review of the record, and comparisons with other Pacific island groups. J. Archaeol. Sci. 16:177-205.

- 1989b. A new species of starling (Sturnidae, Aplonis) from an archaeological site on Huahine, Society Islands. Notornis 36:161-169.

-1992. New species of Gallicolumba and Macropygia (Aves: Columbidae) from archaeological sites in Polynesia. Los Angel. Cty. Mus. Nat. Hist., Sci. Ser. 36:329-348.

. 1995. Prehistoric extinctions of Pacific island birds: Biodiversity meets 
zooarchaeology. Science (Washington, D.C.) $267: 1123-1131$.

2002. A new species of gull (Laridae: Larus) from an archaeological site on Huahine, Society Islands. Proc. Biol. Soc. Wash. 115:1-17.

. In press. Extinction and biogeography of tropical Pacific birds. University of Chicago Press, Chicago.

Steadman, D. W., and D. S. Pahlavan. 1992. Extinction and biogeography of birds on Huahine, Society Islands, French Polynesia. Geoarchaeology 7:449-483.

Steadman, D. W., and B. Rolett. 1996. A chronostratigraphic analysis of landbird extinction on Tahuata, Marquesas Islands. J. Archaeol. Sci. 23:81-94.

Steadman, D. W., and M. C. Zarriello. 1987. Two new species of parrots (Aves: Psitta- cidae) from archaeological sites in the Marquesas Islands. Proc. Biol. Soc. Wash. 100:518-528.

Steadman, D. W., T. H. Worthy, A. J. Anderson, and R. Walter. 2000. New species and records of birds from prehistoric sites on Niue, Southwest Pacific. Wilson Bull. 112:165-186.

Taylor, P. B. 1998. Rails: A guide to the rails, crakes, gallinules and coots of the world. Yale University Press, New Haven, Connecticut.

Worthy, T. H., and R. N. Holdaway. 2002. The lost world of the moa. Indiana University Press, Bloomington.

Wragg, G. M. 1995. The fossil birds of Henderson Island, Pitcairn Group: Natural turnover and human impact, a synopsis. Biol. J. Linn. Soc. 56:405-414. 
